\title{
Ballistic Studies on Fox-7 Based Triple Base Propellant for High Calibre Gun
}

\author{
SM Dahiwale ${ }^{1 *}$, Chetan Bhongale ${ }^{2 *}$ and SN Asthana ${ }^{1}$ \\ ${ }^{1}$ Gun Propellant System group, High Energy Materials Research Laboratory, India \\ ${ }^{2}$ Department of Applied Chemistry, Defence Institute of Advanced Technology (Deemed University), India
}

Submission: February 02, 2019; Published: March 20, 2019

*Corresponding author: SM Dahiwale, Gun Propellant System group, High Energy Materials Research Laboratory, Sutarwadi, Pune, India Chetan Bhongale, Department of Applied Chemistry, Defence Institute of Advanced Technology (Deemed University), India

\begin{abstract}
In the present work, triple base propellant (TBP) containing mainly energetic nitrate polymer nitrocellulose and nitroglycerine, picrite, 1,1-diamino-2,2-dinitroethene (FOX-7) along with ingredients such as stabiliser and plasticizer has been processed by solvent method. Picrite has been replaced in increments with FOX-7 from the propellant composition. Acetone: ethanol used as solvent to gelatinise/plasticize NC during processing. Dimensions of the propellant was determined by physical measurement and propellant grains were subjected to mechanical properties (compressive strength (CS), \% compression) determination, sensitivity tests and closed vessel (CV) firing. Incorporation of FOX-7 led to remarkable increase in $\mathrm{CS}$ at sub-zero temperatures $\left(-20^{\circ} \mathrm{C}\right)$ and reduced at higher temperatures $\left(+55^{\circ} \mathrm{C}\right)$ for $20 \%$ FOX-7 in TBP composition. $\mathrm{CV}$ test of the propellant was carried out at $0.2 \mathrm{~g} / \mathrm{cc}$ loading density in $700 \mathrm{cc}$ closed vessel at $+21,-20 \&+55^{\circ} \mathrm{C}$ to evaluate ballistic parameters such as Pmax, force constant, (dP/dt) max, pressure index ( $\alpha$ ), burning rate coefficient ( $\beta$ ), rise time, relative force (RF) and relative vivacity (RV). The trends observed during this work bring out the potential of FOX-7 to impart temperature independent characteristics in the TBP used for high calibre gun.
\end{abstract}

Keywords: FOX-7; Pressure index; Force constant; Burning rate; Chamber pressure

\section{Introduction}

Table 1: Materials assay and source.

\begin{tabular}{|c|c|}
\hline Materials & Assay \& source \\
\hline Nitrocellulose (NC) & N 12.2\%, ether-alcohol solubility $>95 \%$, Director General, Ordnance Factory \\
\hline Nitroglycerine (NG) & N $18.3 \%$, Bharat Explosives, India \\
\hline NC-NG paste & Ratio $54.3: 45.7$, Bharat Explosives, India \\
\hline Nitroguanidine (picrite) & Purity $98.8 \%$ by mass, specific area $19798 \mathrm{~cm}^{2} / \mathrm{cm}^{3}$, Director General, Ordnance Factory \\
\hline 1,1-diamino-2,2-dinitroethene (FOX-7) & Particle size $25 \mu \mathrm{m}$, Purity $99.5 \%$, Director General, DRDO \\
\hline Carbamite & Purity $99.8 \%$, Director General, Ordnance Factory \\
\hline Potassium sulphate & Purity $98.8 \%$, Director General, Ordnance Factory \\
\hline Dibutyl phthalate (DBP) & Density $1.04 \mathrm{~g} / \mathrm{cm}^{3}$ at $27^{\circ} \mathrm{C}$, Purity $>99.9 \%$, Aldrich, Germany \\
\hline Acetone & Purity $99.8 \%$, Aldrich, Germany \\
\hline Ethanol & Purity $>96 \%$, D Fine Chemicals, India \\
\hline Graphite & Purity $99.98 \%$, particle size $<20 \mu$ m, Sigma Aldrich, Germany \\
\hline
\end{tabular}

FOX-7 or 1,1-diamino-2,2-dinitroethene (DADNE) as reported by Lochert [1] is a low vulnerable energetic compound. It was first synthesized in 1990s by the FOA Defence Research Establishment (Sweden). However, its application in propellant has received at- tention during last decade. The performance of FOX-7 is comparable to cyclotrimethylene trinitramine (RDX) whereas its impact and friction sensitivities are much less than that of RDX and other nitramines. Calculated detonation velocity of FOX-7 based high 
energy compositions has been of the order $9090 \mathrm{~m} / \mathrm{s}$ compared to $8800 \mathrm{~m} / \mathrm{s}$ for RDX based compositions [1-3]. FOX-7 has a potential for application in high performance IM-compliant explosive formulations. Most of the research establishments working in the area of high energy materials (HEMs) like Aeronautical and Maritime Research Laboratory (AMRL) have focused on the synthesis, hazards characterisation and performance evaluation of FOX-7.
Dorsett [4] has mentioned in the report that 1,1-diamino-2,2-dinitroethene i.e. FOX-7 is like the insensitive chemical compound triamino trinitro benzene (TATB), a benzene ring compound having three amino and three nitro groups. FOX-7 has a two-carbon backbone in place of a benzene ring, but the amino and nitro groups have similar effects in both cases according to published reports on sensitivity and chemical decay processes of FOX-7 [5] Table 1.

Table 2: Chemical analysis results of TBP using HPLC model No. Ultimate 3000.

\begin{tabular}{|c|c|c|c|c|c|c|c|c|}
\hline Comp & NC & NG & Picrite & FOX-7 & DBP & Carbamite & $\mathbf{K}_{\mathbf{2}} \mathbf{S O}_{\mathbf{4}}$ & $\mathbf{G r a p h i t e}$ \\
\hline TBP & 32.3 & 24.2 & 38.6 & -- & 1.96 & 0.96 & 1.93 & 0.05 \\
\hline FB-05 & 32.3 & 24.2 & 33.71 & 4.89 & 1.96 & 0.96 & 1.93 & 0.05 \\
\hline FB-20 & 32.3 & 24.2 & 18.8 & 19.8 & 1.96 & 0.96 & 1.93 & 0.05 \\
\hline
\end{tabular}

It is mainly produced by Eurenco Bofors AB \& Sweden [1,6,7]. Some of the characteristics of FOX-7 vis-a-vis RDX and picrite are given in Table 2. Various tests such as slow cook off, fast cook off, bullet impact test have been conducted along with Composition B to establish the insensitive nature of FOX-7 based propellants. Most of the reported literature pertains to FOX-7 based plastic bonded explosives. FOX-7 based compositions have undergone deflagration (type $\mathrm{V}$ reaction) whereas, Composition $\mathrm{B}$ has given detonation response (type I reaction). Burn rate $(\mathrm{mm} / \mathrm{s})$ was found to increase with pressure (MPa) and force constant $(\mathrm{J} / \mathrm{g})$ was found to increase with temperature.

Thus, FOX-7 enhanced the safety of propellant without much compromise on propellant energy. Mishra et al [3] have also studied lower vulnerability of FOX-7 based, non-aluminized and aluminized, melt cast explosive with marginal decrease in performance compared to RDX based compositions. S Karlsson [8] has reported height of $50 \%$ explosion $\left(\mathrm{H}_{50}\right) 63-79 \mathrm{~cm}$ in Drop hammer tests and no reaction in the friction test $(>340 \mathrm{~N})$. A castable composition of FOX-7 and poly-glycidyl nitrate (Poly-GLYN) has also been studied by these researchers. Limited safety tests indicated that the compositions with FOX-7 were less sensitive to friction, it had excellent thermal stability at $65^{\circ} \mathrm{C}$ and slow cook-off stimuli. It did not detonate at a diameter of $25 \mathrm{~mm}$ and upon slow heating $\left(3.3^{\circ} \mathrm{C}\right.$ /hour) it ignites at $220^{\circ} \mathrm{C}$ and burns without damage to the container or the surroundings. Limited work has been reported in literature on FOX-7 based propellant. Wuxi Xie et al. [9] studied the performance of Nitrate Ester Plasticized Polyether (NEPE) rocket propellants containing FOX-7 as replacement of Cyclotetramethylene tetranitramine (HMX). They observed decrease in combustion temperature by about $100 \mathrm{~K}$ and increase in burning rate as well as pressure exponents. Moreover, tensile strength of the propellants was increased, whereas maximum elongation decreased by about $40 \%$. The initiation probability under pressure decreased by $12 \%$ along with decrease in friction sensitivity of the propellant suggesting improved insensitivity characteristics. Bogdan Florczak [10] observed that, the propellant containing FOX-7 has a comparable deflagration temperature and gaseous reaction products volume as the composite propellant containing the same amount of HMX. Linear burn rate of propellant formulation containing FOX-7 is nearly $17 \%$ less than that of the propellant formulation containing HMX. Hendrik Lips et al. [11] has studied FOX-7 / Ammonium perchlorate (AP) / Glycidyl Azide Polymer (GAP) based rocket propellants for a shoulder launched projectile. It is found that formulations containing FOX-7, AP and GAP exhibit a plateau burning behaviour between pressure values of 7 and $12 \mathrm{MPa}$, like double base propellants. Chemical stability and sensitivity test also within acceptable limits. FOX-7/ polyurethane compositions with nitro plasticizers exhibit the best thermal stability. Shock sensitivity test results of FOX-7 based propellant correspond to values with a hazard division (HD) 1.3. However, the mechanical properties need further improvement.

As limited studies are reported on FOX-7 based gun propellant, the present work was undertaken to study FOX-7 as a component of triple base gun propellant with NC as polymeric energetic binder.

\section{Experimental Section}

\section{Materials}

NC-NG paste having volatile matter (VM) content $0.4 \%$ and other ingredients weights are taken on dry weight basis for processing the propellant batch. NC-NG paste, picrite and FOX-7 loaded into incorporator for kneading and solvent (17-25\%) along with di-butyl phthalate to form homogenous and fully consistent dough, warm water circulation started $\left(38-40^{\circ} \mathrm{C}\right)$. Propellant processing was carried out by well-established method. (Surjit Singh Vol-II [12].

Chemical analysis of TBP was carried out using high performance liquid chromatography (HPLC) model No. Ultimate 3000. This model of HPLC is manufactured by Dionex Softron GmbH, Germering, Germany. The HPLC column has a neutral stationary phase containing $\mathrm{C} 18$, octadecasilane with the dimensions of $250 \mathrm{~mm}$ length, $4.6 \mathrm{~mm}$ diameter and $5 \mu \mathrm{m}$ pore size. Mobile phase included methanol: water (70:30) mixture. Propellant sample was ground, and ether extract was prepared by heating the content in water bath. It was injected into the HPLC column. The system is run for a duration of 30 minutes by conditioning at a temperature of $35^{\circ} \mathrm{C}$ at a standard flow rate of mobile phase of $1 \mathrm{ml} / \mathrm{min}$ and 64 bar pressure in reverse phase. Content of polymeric binder NC, graphite and $\mathrm{K}_{2} \mathrm{SO}_{4}$ in the propellant is calculated by difference. In 
order to obtain only $\mathrm{NC}$ and graphite content in the propellant, the residue of ether extract is treated with hot water. $\mathrm{K}_{2} \mathrm{SO}_{4}$ gets dissolved in hot water that was estimated by well-known methods. To estimate graphite, acetone is added in the remaining extract to dissolve NC. Chemical analysis results are given below in Table 3.

Table 3: Some important properties reported in literature [3,4].

\begin{tabular}{|c|c|c|c|}
\hline Properties & RDX & Picrite & FOX-7 \\
\hline Molecular weight & 222 & 104 & 148 \\
\hline Density $(\mathrm{g} / \mathrm{cc})$ & 1.82 & 1.72 & 1.87 \\
\hline Melting point $\left({ }^{\circ} \mathrm{C}\right)$ & 204 & 232 & 238 \\
\hline Nitrogen content $(\%)$ & 37.83 & 53.84 & 47.11 \\
\hline$\Delta \mathrm{H}_{\mathrm{f}}(\mathrm{kcal} /$ mole) & 16 & -22.2 & -32 \\
\hline Oxygen balance $(\%)$ & -21.6 & -30.7 & -21.6 \\
\hline Impact sensitivity (cm) & 38 & 76 & 70 \\
\hline Friction sensitivity (N) & 120 & 353 & 353 \\
\hline
\end{tabular}

Table 4: Theoretical calculation of FOX -7 based TBP using THERM program.

\begin{tabular}{|c|c|c|c|c|}
\hline Sr No. & $\begin{array}{c}\text { Thermochemical } \\
\text { parameter }\end{array}$ & Std TBP & FB-05 & FB-20 \\
\hline 1 & Flame temperature (T0) (K) & 2934 & 3050 & 3386 \\
\hline 2 & Force constant $(\mathrm{F})(\mathrm{J} / \mathrm{g})$ & 1031 & 1062 & 1148 \\
\hline 3 & $\begin{array}{l}\text { Pressure of explosion (Pm) } \\
(\mathrm{MPa})\end{array}$ & 253 & 261 & 282 \\
\hline 4 & $\begin{array}{l}\text { No of moles of gas formed } \\
\text { (n) }(\mathrm{mol} / \mathrm{g})\end{array}$ & 0.04 & 0.04 & 0.041 \\
\hline 5 & Specific heat (Cv) (Cal/g/C) & 0.35 & 0.35 & 0.34 \\
\hline 6 & Co-volume (eta) (cc/g) & 0.93 & 0.93 & 0.93 \\
\hline 7 & Gamma $\left(C_{p} / C_{v}\right)$ & 1.24 & 1.24 & 1.24 \\
\hline 8 & Calorific value (Q) (Cal/g) & 923 & 962 & 1072 \\
\hline 9 & $\begin{array}{l}\text { Mean molecular weight of } \\
\text { gases }(\mathrm{m})(\mathrm{g} / \mathrm{mole})\end{array}$ & 23.66 & 23.88 & 24.53 \\
\hline 10 & Gas volume (v) (cc/g) & 947 & 938 & 913 \\
\hline 11 & $\begin{array}{l}\text { Heat of formation of } \\
\text { propellant }\left(\mathrm{H}_{\mathrm{f}}\right)(\mathrm{Cal}) / \mathrm{g}\end{array}$ & 414 & 394 & 339 \\
\hline 12 & $\begin{array}{l}\text { Internal energy of product } \\
\text { gases }(\mathrm{E})(\mathrm{Cal} / \mathrm{g})\end{array}$ & 820 & 858 & 968 \\
\hline
\end{tabular}

Thermo chemical parameters for all the experimental propellant compositions that is processed are calculated using THERM program of HEMRL are given in Table 4. In this program, some basic thermodynamic equations that are reported for gun propellant combustion have been used for calculations [13-19]. Approximate determination of temperature of explosion is carried out using computer program. Then the calculation of heat of reaction of gas and its internal energy is carried out. Number of gram atom/gram of $\mathrm{C}, \mathrm{H}, \mathrm{N}, \mathrm{O}$ are given by well-known and reported equation. The energy released at $2500 \mathrm{~K}$ is evaluated making use of well-reported combustion parameters for $\mathrm{C}, \mathrm{H}, \mathrm{N}, \mathrm{O}$. The major products of propellant combustion are predicted viz. $\mathrm{CO}_{2}, \mathrm{H}_{2} \mathrm{O}, \mathrm{H}_{2}$, $\mathrm{N}_{2}$ gases and dissociation products are $\mathrm{OH}, \mathrm{H}, \mathrm{NO}, \mathrm{O}$. Calculation of internal energy of these gases is carried out by applying standard thermodynamic equations. Thereafter, other important and quite relevant constants such as co-volume, force constant and heat of combustion are calculated and compared with values reported in the literature. Detailed research work involving computer program had been published by K P Rao [12]. Researchers have been using this program widely for approximate calculation of ballistic parameters pertaining to gun propellants [20-24].

Measurement of dimensions of dried propellant grain was carried out using Vaiseshika Zoom Stereoscopic Microscope Type 7004 TNC Sr. No. 99075 having resolution 7X to 60X manufactured by M/s Vaiseshika Electronic Devices, Ambala Cantt, Haryana, India. The propellant grain is held in different positions under the microscope which is connected to a programmed computer and image is frozen and thereafter various dimensions such as web size, hole size, grain diameter, length etc. are measured in $\mathrm{mm}$ by moving the crosswire from point to point in the frozen image. Movement of crosswire across the image gives the length or distance between the two selected points on the image that is displayed and recorded by a programmed computer connected to the microscope. Geometrical parameters of FOX 7 based TBP grains are tabulated in Table 5. Photograph of a few propellant grains taken using camera make Sony Japan. Model No. Cyber-shotDSC-S980, 12.1 Mega pixel, Optical zoom 4X is placed at Figure 1.

Table 5: Geometrical parameters of FOX 7 based TBP grains.

\begin{tabular}{|c|c|c|c|c|c|}
\hline Propellant & $\begin{array}{c}\text { Hole dia } \\
\text { (mm) }\end{array}$ & $\begin{array}{c}\text { Web } \\
\text { (mm) }\end{array}$ & $\begin{array}{c}\text { Grain } \\
\text { length } \\
\text { (mm) }\end{array}$ & $\begin{array}{c}\text { Form } \\
\text { function }\end{array}$ & TWF \\
\hline Std TBP & 0.767 & 2.166 & 22 & -0.211 & 1.0197 \\
\hline FB-05 & 0.759 & 2.039 & 23 & -0.216 & 1.0197 \\
\hline FB-20 & 0.742 & 2.187 & 23 & -0.216 & 1.0193 \\
\hline
\end{tabular}

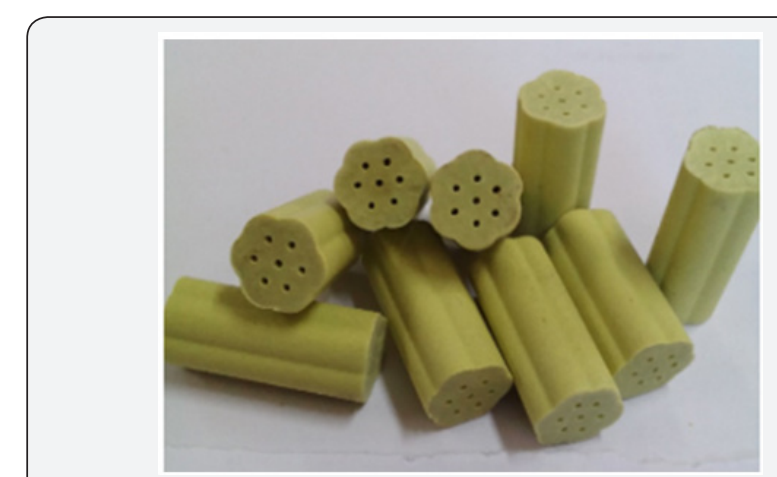

Figure 1: Photograph of FOX-7 based triple base propellant.

Form function is a measure of surface area of the propellant grain and theoretical web factor (TWF) is the ratio of ballistic web to geometric web is calculated using available computer program $[11,12]$. Input parameters like grain geometry, hole size, diameter, length: diameter ratio is given as input parameters for calculation and form function and TWF are obtained as output parameters. Mechanical properties testing was carried out using Hounsfield Universal Testing Machine H25KN, New York, US. Length: diameter (L/D) ratio of propellant grain was adjusted to 2.0 and condi- 
tioned at $+21,-20 \&+55^{\circ} \mathrm{C}$ for 4 hours. Mechanical properties viz. compressive strength (CS) and \% compression of the propellant grains was determined.

Impact sensitivity and test was carried out using BAM IM Fall Hammer apparatus make Chilworth Technology, UK, with $2 \mathrm{~kg}$ drop weight. Friction sensitivity test was conducted using BAM FR Friction test apparatus, make Chilworth Technology, UK. Similarly, autoignition temperature was determined using Wood's metal bath. During all the three tests propellant sample was powdered by grinding and $150-300 \mu \mathrm{m}$ particle size was taken evaluation $[6,25]$.

Closed vessel evaluation of FOX-7 based propellant along with standard TBP (Std TBP) was carried out at $0.2 \mathrm{~g} / \mathrm{cc}$ loading density in $700 \mathrm{cc} C \mathrm{CV}$ [26] after conditioning at $+21,-20 \&+55^{\circ} \mathrm{C}$ for 24 hours to determine ballistic parameters such as $\mathrm{P}_{\text {max }}$, force constant, $(\mathrm{dP} / \mathrm{dt})_{\max }$ pressure index $(\alpha)$, burning rate coefficient $(\beta)$, rise time, vivacity, relative force (RF) and relative vivacity (RV) $[19,27]$. Measurement of pressure during CV firing was done using tourmaline piezo-electric gauge. $1.2 \mathrm{~g}$ gunpowder was used to ignite the main propellant charge. Nearly 4 ampere current was passed through a thin nichrome wire having length $22-25 \mathrm{~mm}$ connected across the firing electrodes closed vessel in order to ignite the gunpowder which then ignites the propellant charge $[28,29]$.

\section{Result and Discussion}

Chemical analysis results of TBP using HPLC is given in Table 2. Some important properties are reported from literature $[3,4]$. It shows that FOX-7 has higher density and oxygen balance as compared to picrite. Result of theoretical calculation (Table 4) shows that, most of the parameters such as flame temperature, force constant, chamber pressure, calorific value, and mean molecular mass are increasing for FOX-7 based propellant compositions as compared to standard TBP which do not contain FOX-7. Geometrical parameters of propellant grains (Table 5) shows that web size, hole size, diameter, length and form function for FOX-7 based compositions grains are comparable to the Std TBP grains.

Table 6: Mechanical properties of FOX-7 based TBP grains.

\begin{tabular}{|c|c|c|c|c|c|c|}
\hline $\begin{array}{c}\text { Temp } \\
\left({ }^{\circ} \text { C) }\right.\end{array}$ & \multicolumn{2}{|c|}{ Std TBP } & \multicolumn{2}{c|}{ FB-05 } & \multicolumn{2}{c|}{ FB-20 } \\
\hline & $\begin{array}{c}\text { CS (kgf/ } \\
\left.\mathrm{cm}^{2}\right)\end{array}$ & $\%$ comp & $\begin{array}{c}\text { CS (kgf/ } \\
\left.\mathrm{cm}^{2}\right)\end{array}$ & $\%$ comp & $\begin{array}{c}\text { CS (kgf/ } \\
\mathrm{cm}^{2} \text { ) }\end{array}$ & $\begin{array}{c}\% \\
\text { comp }\end{array}$ \\
\hline-20 & 278 & 32 & 233 & 26 & 344 & 33 \\
\hline 21 & 315 & 62 & 192 & 47 & 236 & 42 \\
\hline 55 & 250 & 56 & 208 & 47 & 227 & 39 \\
\hline
\end{tabular}

Mechanical properties such as compressive strength (CS) and $\%$ compression after conditioning at $+21,-20 \&+55^{\circ} \mathrm{C}$ for four hours are given in Table 6 . The result shows that incorporation of FOX-7 at 5\% level bring down the CS whereas increase in FOX-7 content to $20 \%$ level results in improvement in CS at all the temperatures. The CS at $-20^{\circ} \mathrm{C}$ for $20 \%$ FOX- 7 based composition is more than that of even Std TBP. However, CS is increasing as the amount of FOX-7 is increased in the propellant grain composi- tion. Incorporation of FOX-7 brought down the \% compression at $+21^{\circ} \mathrm{C}$. These results suggest that incorporation of FOX-7 renders the TBP hard at sub-zero conditioning temperatures probably due to reinforcement by FOX-7 particles involving physical forces (hydrogen bonding). It is possible that microcracks may be developing in the FOX-7 based TBP grains at sub-zero conditioning temperatures offering greater burning surface resulting in combustion stability and near to temperature independent ballistics of gun propellant. This is on the lines of the work already reported. The results also suggest that FOX-7 based TBP can retain structural integrity even at higher temperature thereby preventing the accidental damage to gun.

Table 7: Sensitivity tests of FOX-7 based TBP.

\begin{tabular}{|c|c|c|c|c|c|}
\hline $\begin{array}{c}\text { Sr } \\
\text { No. }\end{array}$ & Composition & \multicolumn{2}{|c|}{ Impact Test } & $\begin{array}{c}\text { Friction } \\
\text { Test }(\mathbf{k g})\end{array}$ & $\begin{array}{c}\text { Autoignition } \\
\text { Temperature } \\
\left({ }^{\circ} \mathbf{C}\right)\end{array}$ \\
\hline & & H50(cm) & FoI & & \\
\hline 1 & Std TBP & 26 & 39 & 36 & 197 \\
\hline 2 & FB-05 & 26 & 39 & 36 & 210 \\
\hline 3 & FB-20 & 27 & 40 & 36 & 238 \\
\hline
\end{tabular}

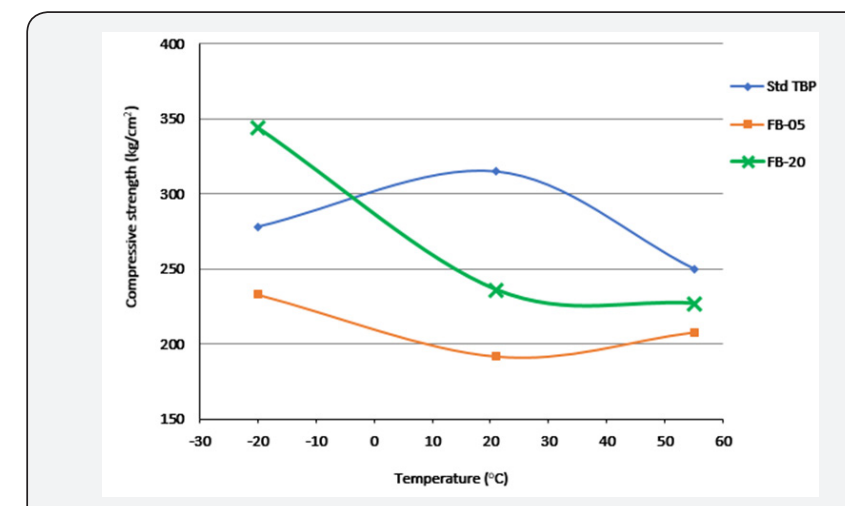

Figure 2: Plot of compressive strength against temperature of FOX-7 based propellant.

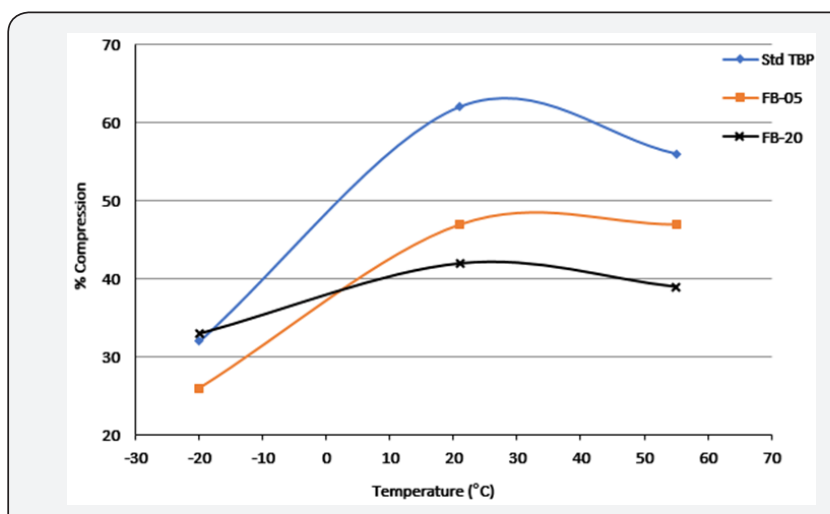

Figure 3: Plot of \% compression against temperature of FOX-7 based propellant.

FOX-7 based propellant grains are stronger at $-20^{\circ} \mathrm{C}$ and weaker at higher temperatures than Std TBP as the value of CS is higher at sub-zero temperature and lower at $+55^{\circ} \mathrm{C}$. The performance at $+21 \&+55^{\circ} \mathrm{C}$ is almost similar. Values of CS are plotted in Figure 2. 
Impact, friction as well as auto-ignition temperature test results are given in Table 7. Auto-ignition test results bring out decrease in vulnerability to thermal stimulus of propellant on incorporation of FOX-7. These results are in line with the reported studies Waldemar A. Trzciński [30]. FOX-7 did not have adverse effect on impact and friction sensitivity of the propellant unlike RDX/ HMX. This may be due to stability gained by the molecules after each oxygen atom of the nitro groups involved with two hydrogen bonding in FOX-7 molecules resulting in two intra-molecular and six inter-molecular hydrogen bonds [31] Figure 3.

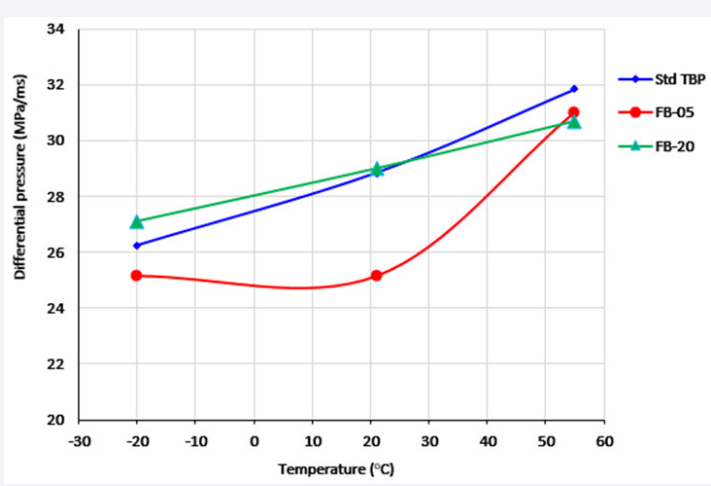

Figure 4: Plot of $\mathrm{CV}$ firing results of differential pressure against temperature.

As depicted in Figure 4, rate of change of pressure i.e. differential pressure attains a maximum value for every composition during CV firing is denoted in terms of $(\mathrm{dP} / \mathrm{dt})_{\max }$. The value of $(\mathrm{dP} / \mathrm{dt})_{\max }$ is lowered for FB- 20 at $+55^{\circ} \mathrm{C}$ whereas it is increased at $-20^{\circ} \mathrm{C}$ and almost coincides at $21^{\circ} \mathrm{C}$ with that of Std TBP. This behaviour of FOX-7 based TBP indicates a trend towards low temperature coefficient propellant.

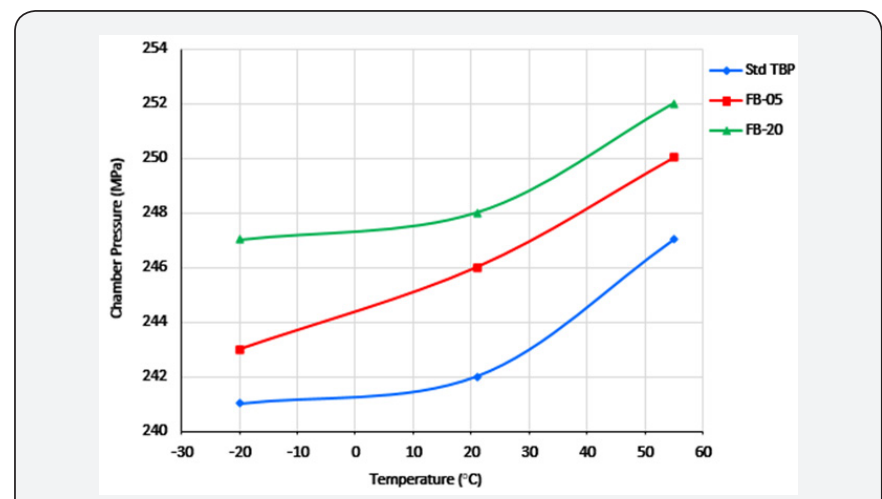

Figure 5: Plot of CV firing results of Chamber pressure $P_{\max }$ against temperature.

Chamber pressure was found marginally higher for FB-05 and FB-20 compositions compared to Std TBP evaluated during this work at $-20^{\circ} \mathrm{C}$ and $21^{\circ} \mathrm{C}$, as shown in Figure 5 whereas it is found to be marginally increased for $\mathrm{FB}-05$ composition at $+55^{\circ} \mathrm{C}$. This may be due to brittleness of FOX-7 based propellant composition which gives rise to increase in surface area and increased burn rate. Increased burn rate increases the amount of gases thereby increasing the gaseous pressure. This trend in pressure indicated that FOX 7 based TBPs are showing low temperature sensitivity [32]. This result shows that FOX-7 based TBP can be used in large calibre guns without hazards.

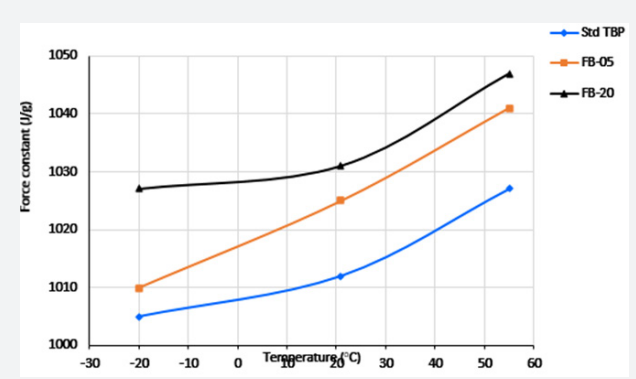

Figure 6: Plot of $\mathrm{CV}$ firing results of force constant against temperature.

Force constant which is a measure of propellant energy is almost same for FB- 20 composition at $-20^{\circ} \mathrm{C}$ and at $21^{\circ} \mathrm{C}$ as compared to Std TBP and FB-05 composition whereas it is increased at $+55^{\circ} \mathrm{C}$. The graph is plotted in Figure 6 . This behaviour of FOX-7 based TBP indicates a trend towards low temperature coefficient propellant in sub-zero temperature region. This may be due to hardening of FOX-7 based propellant grain making it more brittle propellant composition which gives rise in surface area and increased burn rate. Increased burn rate increases flame temperature and gaseous molecules move faster giving more force or energy (Table 4) [30]. CV firing results bring out increase in force constant with increase in FOX-7 content in the propellant at replacement of picrite. This may be attributed to higher density and superior oxygen balance (stoichiometry) of FOX-7 compared to picrite.

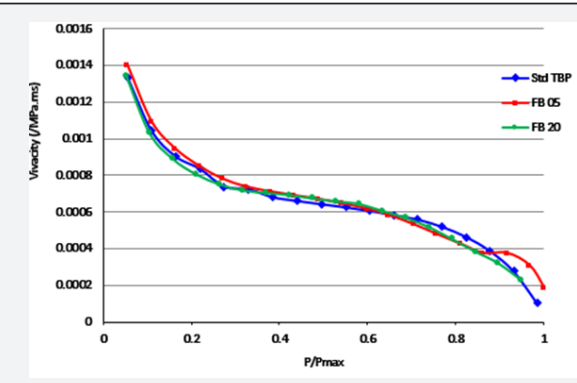

Figure 7: Plot of $\mathrm{CV}$ firing results of Vivacity against normalized pressure at $-20^{\circ} \mathrm{C}$.

Dynamic vivacity expressed as $\left[(1 / \mathrm{P}) \cdot\left(1 / \mathrm{P}_{\max }\right) \cdot(\mathrm{dP} / \mathrm{dt})\right]$ is plotted against normalized pressure $\left(\mathrm{P} / \mathrm{P}_{\max }\right)$. A comparison of Figure 7-9 corresponding to $\mathrm{CV}$ tests at $-20,+21$ and $+55^{\circ} \mathrm{C}$ respectively shows that graph of vivacity for FB-20 composition begins on the lower side as compared to FB-05 and marginally higher than Std TBP and it remains on the lower side for entire range of normalized pressure. It indicates comparative lowering of the production of gases at all temperatures of conditioning for FB-20 propellant composition and particularly at $+55^{\circ} \mathrm{C}$. This clearly brings out the fact that FOX-7 based propellant composition has the potential for exhibiting low temperature coefficient ballistic parameters. Similar is the trend in case of RV as observed from the graph between RV versus temperature shown in Table 8. 


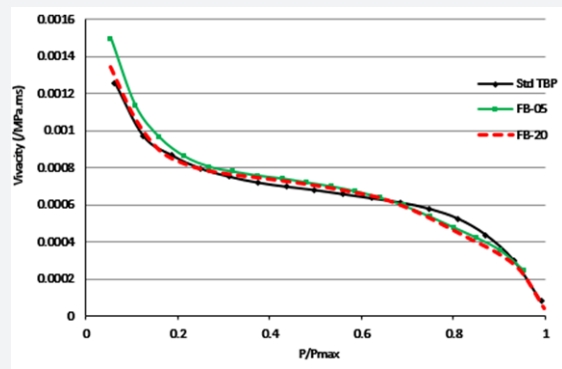

Figure 8:Plot of $\mathrm{CV}$ firing results of Vivacity against normalized pressure at $+21^{\circ} \mathrm{C}$

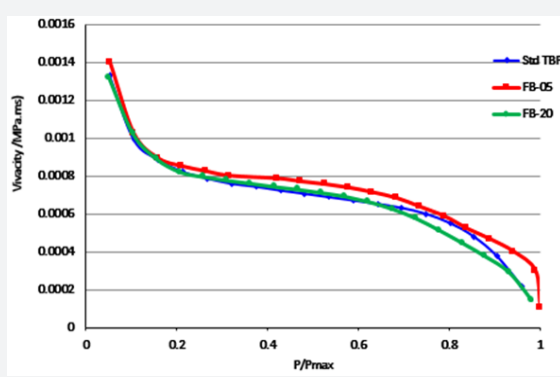

Figure 9: Plot of $\mathrm{CV}$ firing results of Vivacity against normalized pressure at $+55^{\circ} \mathrm{C}$

Table 8: Closed vessel firing results of FOX-7 based TBP at $-20^{\circ} \mathrm{C}$.

\begin{tabular}{|c|c|c|c|}
\hline Parameters & Std TBP & FB-05 & FB-20 \\
\hline $\mathrm{F}(\mathrm{J} / \mathrm{g})$ & 1005 & 1010 & 1027 \\
\hline $\mathrm{P}_{\text {max }}(\mathrm{MPa})$ & 241 & 243 & 247 \\
\hline $\begin{array}{c}(\mathrm{dP} / \mathrm{dt})_{\text {max }} \\
(\mathrm{MPa} / \mathrm{ms})\end{array}$ & 26.25 & 25.16 & 27.1 \\
\hline$\alpha$ & 0.6628 & 0.6479 & 0.6836 \\
\hline$\beta$ & 0.6833 & 0.7139 & 0.6365 \\
\hline$\beta_{1}$ & 0.1157 & 0.1116 & 0.1207 \\
\hline Rise time (ms) & 13.5 & 13.1 & 13.18 \\
\hline $\begin{array}{c}\text { Vivacity (/MPa. } \\
\mathrm{ms})\end{array}$ & $6.49 \mathrm{X} 10^{-4}$ & $6.53 \times 10^{-4}$ & $6.64 \mathrm{X10^{-4 }}$ \\
\hline $\mathrm{RF}$ & 100 & 100.46 & 103.9 \\
\hline $\mathrm{RV}$ & 100 & 103.71 & 104.47 \\
\hline
\end{tabular}

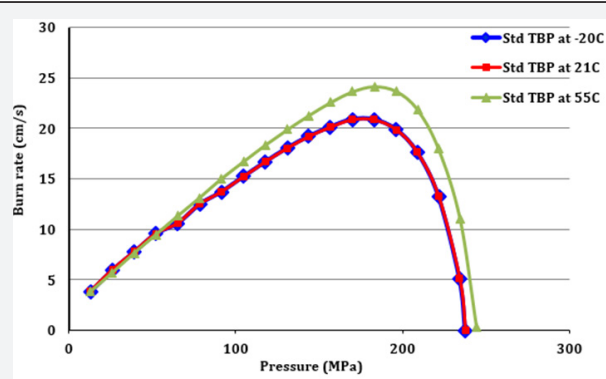

Figure 10: Plot of CV firing results of burn rate of Std TBP against pressure.

Burn rate versus pressure profile obtained during CV firing of FOX-7 based propellant compositions at $-20,21 \&+55^{\circ} \mathrm{C}$ re- spectively plotted in Figure 10-12. Graph shows that burn rate increases with increase of temperature and attains peak at certain pressure and then falls off steeply even though the pressure increases as the propellant gets consumed fully. It may be noted that the burn rate is lowered as the FOX-7 content is increased in the propellant compositions. Burn rate for FOX-7 based composition FB-05 is reduced as compared to Std TBP; however, for FB-20 it was close to that for Std TBP at $-20^{\circ} \mathrm{C}$ whereas at $+55^{\circ} \mathrm{C}$ for FOX-7 based composition gave marginally lower burn rates at $\mathrm{P}_{\max }$ compared to Std TBP. These results are indicative of introduction of temperature independent/less dependent combustion of FOX-7 based TBP. It increases the duration of combustion. This indicates that pressure may act on the base of projectile for a longer duration increasing its velocity [Table $9 \& 10$ ].

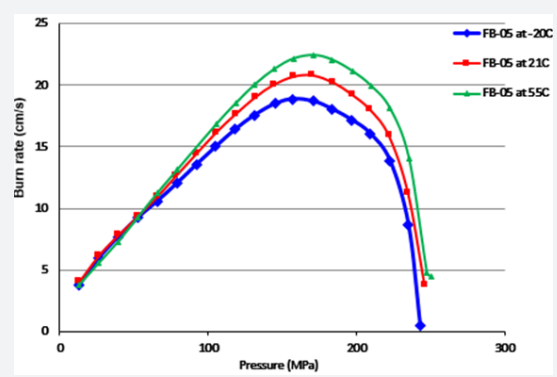

Figure 11: Plot of CV firing results of burn rate of FB-05 against pressure.

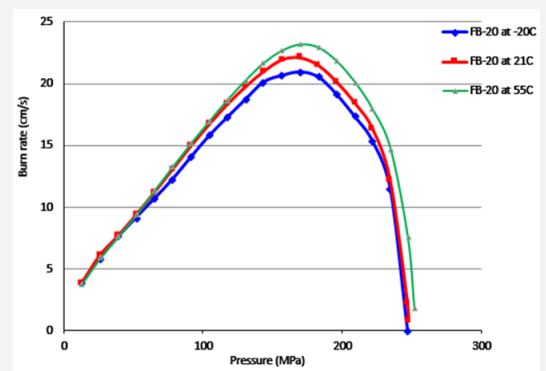

Figure 12: Plot of $\mathrm{CV}$ firing results of burn rate of FB-20 against pressure.

Table 9: Closed vessel firing results of FOX-7 based TBP at $+21^{\circ} \mathrm{C}$.

\begin{tabular}{|c|c|c|c|}
\hline Parameters & Std TBP & FB-05 & FB-20 \\
\hline F (J/g) & 1012 & 1025 & 1031 \\
\hline Pmax (MPa) & 242 & 246 & 248 \\
\hline $\begin{array}{c}\text { (dP/dt)max (MPa/ } \\
\text { ms })\end{array}$ & 28.84 & 25.16 & 29 \\
\hline$\alpha$ & 0.6979 & 0.662 & 0.7 \\
\hline$\beta$ & 0.6059 & 0.7101 & 0.61 \\
\hline$\beta_{1}$ & 0.124 & 0.1199 & 0.1284 \\
\hline Rise time (ms) & 13.05 & 12.3 & 12.6 \\
\hline Vivacity (/MPa.ms) & $6.61 \times 10^{-4}$ & $7.16 \times 10^{-4}$ & $6.89 \times 10^{-4}$ \\
\hline RF & 100 & 101.23 & 102 \\
\hline RV & 100 & 106.31 & 109 \\
\hline
\end{tabular}


Table 10: Closed vessel firing results of FOX-7 based TBP at $+55^{\circ} \mathrm{C}$.

\begin{tabular}{|c|c|c|c|}
\hline Parameters & TBP & FB-05 & FB-20 \\
\hline F (J/g) & 1027 & 1041 & 1047 \\
\hline Pmax (MPa) & 247 & 250 & 252 \\
\hline $\begin{array}{c}(\mathrm{dP} / \mathrm{dt}) \\
\mathrm{max}(\mathrm{MPa} / \mathrm{ms})\end{array}$ & 31.82 & 31 & 30.7 \\
\hline$\alpha$ & 0.7319 & 0.73 & 0.7253 \\
\hline$\beta$ & 0.54 & 0.5339 & 0.5599 \\
\hline$\beta_{1}$ & 0.1327 & 0.1299 & 0.133 \\
\hline Rise time (ms) & 12.55 & 12.05 & 12.38 \\
\hline $\begin{array}{c}\text { Vivacity (/MPa. } \\
\mathrm{ms})\end{array}$ & $7.0 \times 10^{-4}$ & $6.96 \times 10^{-4}$ & $7.05 \times 10^{-4}$ \\
\hline $\mathrm{RF}$ & 100 & 101.38 & 103.04 \\
\hline $\mathrm{RV}$ & 100 & 105.44 & 102.49 \\
\hline
\end{tabular}

\section{Conclusion}

FOX-7 based gun propellant has given improved energetics and ballistic properties as compared to conventional TBP. Force constant, $\mathrm{P}_{\text {max }}(\mathrm{dP} / \mathrm{dt})_{\max }$, and $\mathrm{RV}$ are on the higher side as compared to standard TBP propellant showing that loading density in high caliber gun can be reduced to get the same muzzle velocity and chamber pressure. Vivacity variation indicates lowering the production of gases at all temperatures of conditioning of the FB20 propellant composition and the rate of generation of gases is further lowered at higher temperatures as compared to Std TBP. This clearly brings out the fact that FB-20 propellant composition has the potential for exhibiting low temperature coefficient ballistic parameters. Similar trend is observed in case of RV versus temperature. Burn rate is lowered and the peak is broadened as the FOX-7 content is increased in the propellant compositions indicating increased duration of combustion. This indicates that pressure may act on the base of projectile for a longer duration increasing its velocity. The trends in ballistics observed bring out the fact that FOX-7 has potential to impart less sensitive, temperature independent characteristics in the TBP used for high calibre gun.

\section{Acknowledgement}

Authors are highly grateful to the Director, HEMRL for his support and permission to prepare the research paper for publication.

\section{References}

1. Ian J Lochert (2001) FOX-7 - A New Insensitive Explosive. DSTOTR-1238, Weapons Systems Division Aeronautical and Maritime Research Laboratory, DSTO Aeronautical and Maritime Research Laboratory 506 Lorimer St Fishermans Bend.

2. Anniyappan M, Talawar MB, Gore GM, Venugopalan S, Gandhe BR (2006) Synthesis, characterization and thermolysis of 1,1-diamino2,2-dinitroethylene (FOX-7) and its salts. Journal of Hazardous Materials 137(2): 812-819.

3. Mishra VS, Vadali SR, Garg RK, Joshi VS, Wasnik RD, et al. (2013) Studies on FOX-7 Based Melt Cast High Explosive Formulations. Central European Journal of Energetic Materials 10(4): 569-580.
4. Helan Dorsett (2000) Computational Studies of FOX-7, a New Insensitive Explosive. National Library of Australia: Catalogue.

5. FOI and Eurenco Bofors AB (2009) Insensitive Munition \& Energetic Materials Technology Symposium.

6. Johan Dahlberg, Per Sjöberg (2004) FOX-7 and its potential applications. EURENCO Bofors AB NDIA Meeting.

7. Karlsson S, Ostmark H, Eldsater C, Carlsson T, Bergman H, et al. (2002) Detonation and Sensitivity Properties of FOX-7 and Formulations Containing FOX-7. 12th Int Symp Detonation San Diego.

8. Wuxi Xie, Yu Zhao, Wei Zhang, Yunfei Liu, Xuezhong Fan, et al. (2018) Sensitivity and Stability Improvements of NEPE Propellants by Inclusion of FOX-7. Propellants Explos Pyrotech 43(3): 308-314.

9. Bogdan Florczak (2008) A Comparison of Properties of Aluminized Composite Propellants Containing HMX and FOX-7. Central European Journal of Energetic Materials 5(3-4): 103-111.

10. Hendrik Lips, Klaus Menke (2013) FOX7/GAP rocket propellants for a shoulder launched projectile. 27th international symposium on ballistics Freiburg.

11. Surjit Singh Hand Book on Solid Propellants.

12. Karir JS (2001) Calculation of Thermochemical Constants of Gun Propellant by Computer Programme THERMO G, HEMRL, Pune India.

13. Rao KP (1979) Calculation of Thermochemical Constants of Propellants. Defence Science Journal 29(1): 21-26.

14. Jacqueline Akhavan (2004) The Chemistry of Explosives: Edition 2. The Royal Society of Chemistry UK 74-100.

15. Longdon L W (1967) Textbook of Ballistics and Gunnery: Part I. Her Majesty's Stationery Office London England 1:1-38.

16. Paul W Cooper, Stanley R Kurowski (1996) Introduction to the Technology of Explosives. pp. 43-55.

17. Farrar CL, Leeming DW (1983) Military Ballistics - A Basic Manual. Brassy Publishers Limited.

18. Rudolf Meyer, Josef Köhler, Axel Homburg (2002) Explosives: ( $5^{\text {th }}$ edn), 293 Wiley, VCH Verlag GmbH \& Co KGaA.

19. Chakraborthy TK, Raha KC, Omprakash, Amarjit Singh B (2004) A Study on Gun Propellants Based on Butyl-NENA. Journal of Energetic Materials 22(1): 41-53.

20. Sanghavi RR, Kamale PJ, Shaikh MAR, Shelar SD, Sunil Kumar K, et al. (2007) HMX based enhanced energy LOVA gun propellant. Journal of Hazardous Materials 143(1-2): 532-534.

21. Rakesh R Sanghavi, Khire VH, Chakraborthy TK, Amarjit Singh (2006) Studies on RDX Influence on Performance Increase of Triple Base Propellants. Propellants, Explosives, Pyrotechnics 31(4): 318-321.

22. Ramdas Damse S, Amarjit Singh (2007) High Energy Propellants for Advanced Gun Ammunition Based on RDX, GAP and TAGN Compositions. Propellants, Explosives, Pyrotechnics 32(1): 52-60.

23. Damse RS, Omprakash B, Tope BG, Chakraborthy TK, Amarjit Singh (2009) Study of N-n-butyl-N-(2-nitroxyethyl) nitramine in RDX based gun propellant. Journal of Hazardous Materials 167(1-3): 1222-1225.

24. Narges Zohari, Seyed Abolfazl Seyed-Sadjadi, Sadegh Marashi-Manesh (2016) The Relationship between Impact Sensitivity of Nitroaromatic Energetic Compounds and their Electrostatic Sensitivity. Central European Journal of Energetic Materials 13(2): 427-443.

25. Pragati Mehta, Chandrakala Shetty P, Ramesh Pundkar N, Himanshu Shekhar (2015) Effect of Loading Densities in Closed Vessel Tests on the Burning Rate of a Propelling Charge. Defence Science Journal 65(2): 126-130. 
26. Jai Prakash Agrawal (2010) High Energy Materials: Propellant Explosives and Pyrotechnics. 2nd edition Wiley-VCH Verlag $\mathrm{GmbH}$ \&Co. KGaA Weinheim: 218-219.

27. Zbigniew Leciejewski, Zbigniew Surma (2011) Effect of Application of Various Ignition Conditions in Closed-Vessel Tests on Burning Rate Calculation of a Fine-Grained Propellant. Combustion, Explosion, and Shock Waves 47(2): 209-216.

28. Jakub Michalski, Zbigniew Leciejewski (2015) Closed Vessel Investigation of Propellant. Ignition Process with Using Capillary Plasma Generator. Problems of Mechatronics: Armament, Aviation, Safety Engineering 6(1-19): 19-26.

29. Waldemar Trzciński A, Amel Belaada (2016) 1,1-Diamino-2,2dinitroethene (DADNE, FOX-7)-Properties and Formulations (a
Review). Central European Journal of Energetic Materials 13(2): 527 544.

30. Markus Fahrni, Beat Vogelsanger, Alfred Steinmann, Bruno Ossola Ulrike Jeck Prosch, et al. (2006) Temperature Independent Propellant Powder. US Patent.

31. Jürgen Evers, Thomas Klapötke M, Peter Mayer, Gilbert Oehlinger, Jan Welch (2006) Energy Density Material, Studied by X-ray Single Crystal and Powder Investigations in the Temperature Range from 200 to 423 K. Inorganic Chemistry 45(13): 4996-5007

32. Moulai Karim Boulkadid, Michel Lefebvre H, Laurence Jeunieau, Alain Dejeaifve (2016) Temperature Sensitivity of Propellant Combustion and Temperature Coefficients of Gun Performance. Central European Journal of Energetic Materials 13(4): 1005-1022.

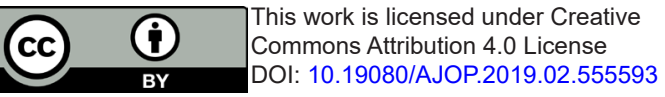

\section{Your next submission with Juniper Publishers will reach you the below assets}

- Quality Editorial service

- Swift Peer Review

- Reprints availability

- E-prints Service

- Manuscript Podcast for convenient understanding

- Global attainment for your research

- Manuscript accessibility in different formats

( Pdf, E-pub, Full Text, Audio)

- Unceasing customer service

Track the below URL for one-step submission https://juniperpublishers.com/online-submission.php 